\title{
INHIBITORY ACTIVITY OF SNAIL (Achatina fulica (Lam.) Bowdich) MUCUS ON GROWTH OF MAMMARY CANCER IN RAT INDUCED WITH DMBA (7,12-DIMETHYLBENZ( $\alpha)$ ANTHRACENE)
}

\author{
Aan Edison ${ }^{1 *}$, Phebe Hendra ${ }^{2}$, B. Boy Rahardjo Sidharta ${ }^{1}$, Sri Herwiyanti ${ }^{3}$, Christy Jacub ${ }^{1}$ \\ ${ }^{1}$ Biology Study Program, Faculty of Biotechnology Universitas Atma Jaya Yogyakarta \\ ${ }^{2}$ Pharmacy Study Program, Faculty of Pharmacy Universitas Sanata Dharma Yogyakarta \\ ${ }^{3}$ Department of Histology and Cell Biology, Faculty of Medicine Universitas Gadjah Mada \\ Yogyakarta
}

Received April 14, 2020; Accepted March 2, 2021

\begin{abstract}
Back to nature as a medication concept has been accepted widely because it has fewer side effects than modern medicines. Researches on natural products as anticancer agent therapies are in progress. This present research was conducted to determine that the inhibitory activity of snail (Achatina fulica (Lam.) Bowdich) mucus inhibits the growth rate of mammary cancer in SpragueDawley rats. Five groups of female rats, with four individuals each, were induced with 7,12dimethylbenz $(\alpha)$ anthracene (DMBA) for five weeks. Snail mucus was applied every seven days to the treated rats with three different dosages $(15,20$, and $25 \mathrm{mg} / \mathrm{kg} \mathrm{BW})$. Observations were done on diameters and growth rate of the mammary cancer lump developed at the end of week $8,10,12$, 14 , and 16. Histopathological examination was carried out at the end of the $16^{\text {th }}$ week. Inhibitory activity results showed a row of average diameter of the cancerous lumps on rats with the following details. The results obtained from the application of snail mucus at dosage of 15, 20, and $25 \mathrm{mg} / \mathrm{kg} \mathrm{BW}$ were at $0.40,0.60$, and $0.09 \mathrm{~cm}$ respectively along with average growth rate of cancerous lumps at $1.50,0.75$, and 0.25 . The histopathology results of the snail mucus treatment at dosage of 15,20 , and $25 \mathrm{mg} / \mathrm{kg}$ BW showed normal tissue depiction and similarly normal histopathological form indicated by the presence of their sub-clinic components. The results showed that a snail mucus dose of $25 \mathrm{mg} / \mathrm{kg}$ BW was able to perform inhibitory activity on growing mammary cancer in rats induced by DMBA.
\end{abstract}

Keywords: Achatina fulica; snail mucus; DMBA; mammary cancer; lump tissue

\section{INTRODUCTION}

Global Cancer Observatory data show that every three minutes on every continent in the world, there are cancer cases that present lethal impact like what occurs in breast cancer cases. Breast cancer contributed $24.2 \%$ of the highest number of cancer cases, followed by cervical cancer (uteri) of $12.1 \%$ (Globocon, 2018). According to the most recent report from Indonesia in 2013 until 2018, the highest number of events in breast cancer was 42.1 per 100,000 populations with an average death rate of 17 per 100,000 populations.

Cancer treatment has been running in Indonesia since 1920. Now, the world cancer day is celebrated every $4^{\text {th }}$ of February. Cancer treatment depends on the level of complexity of the growing cancer cells of which are usually treated with surgery, radiation and chemotherapy chemicals, and immunotherapy (Globocon, 2018). In Indonesia, there are at least 170 to 190 types of cancer cases out of one hundred thousand

*Corresponding author: Aan Edison

Email: Aanedison@gmail.com 
patients, so there must be a proper diagnosis of cancer. Mammary breast cancer is one of the most discussed topics in Indonesia cancer study. It is caused by carcinogenesis process that improves cell abnormalities (Patrick, 2013).

Future research is attracted to the substance 7,12-dimethylbenz $(\alpha)$ anthracene (DMBA) as a cancer carcinogenic substance (Wongso \& Iswahyudi, 2013). 7,12dimethylbenz $(\alpha)$ anthracene also known as DMBA belongs to the polycyclic aromatic hydrocarbon group (Pitot \& Dragan, 1996). DMBA metabolites are the main components of the free form of dihydrodiol. They are potent mutagens in normal mammalian cells (Pitot \& Dragan, 1996). Snail mucus (Achatina fulica) is used as an anti-cancer treatment which causes healthy tissue stratum to remain healthy but cancerous cells to be inhibited (Matusiewicz et al., 2018).

Snails (Achatina fulica (Lam.) Bowdich) - snails or by other names Giant African land snail-were found in Bali in 1822 in the remote areas of Bali, Nusa Penida, and Nusa Lembongan (Hoffman et al., 2014; Vermeulen \& Whitten, 1998). The results of the study by Matusiewicz et al. (2018) show that the protein fraction extracted from snails provides a chemo preventive healing effect on cancer cells. Anticancer inhibitory activity of protein fraction through the induction of apoptosis is performed by inhibiting the expression of enzyme topoisomerase (Ekobon et al., 2016). This expression prevents protein topoisomerase initiated by DMBA from inhibiting the formation of cancer cells DNA (Wongso \& Iswahyudi, 2013).

Mucus is a natural material from the secretory snails (Achatina fulica) with thick concentration in the form of amino acids such as glutamic acid, aspartate, glycine, alanine, and histidine. Clear yellow mucus with $99 \%$ moisture contains $4 \mathrm{mg} / \mathrm{cm}^{3}$ protein. Acharan sulfate is also found in snails (Achatina fulica), which is a part of glycosaminoglycan that has a main recurrent disaccharide structure Alpha-DNacetylglucosaminyl and 2-O-sulfoalpha-L- iduronic acid as a potential cytotoxic agent (Islam \& Linhart, 2003). This study aims to determine the inhibitory activity of snail mucus on the growth of mammary cancer in rats induced with DMBA. Observations were done on diameters and growth of the mammary cancer lumps developed at the end of week $8,10,12,14$, and 16 .

\section{METHODS}

Snail mucus (Achatina fulica) was obtained from snail breeders in Djengkol Hamlet, Sragen, Central Java, Indonesia. Materials needed for chemical carcinogenic test induction were 7,12dimethylbenz $(\alpha)$ anthracene (Sigma Aldrich) substances. The histopathological method was hematoxylin and eosin of $1 \%$ staining. Test animals were laboratory rats (Rattus norvegicus), non-pregnant females SpragueDawley and aged 40 days with weight of 60 grams (rat was obtained from veterinary of Gadjah Mada University, Yogyakarta). This study has obtained ethical clearance from the Ethical Clearance Committee of the Health Research Bioethics Committee, Duta Wacana Christian University with Number EC/960/C.16/FK/2019.

\section{Snail (Achatina fulica) mucus preparation} Snail Achatina fulica mucus was freshly harvested from six kilograms of living snails during the four weeks of the study. Mucus was removed from the snail body by suppressing suppressors' stimulation at the snail shell hole. Mucus would come out about \pm 1 to $2 \mathrm{ml}$ when suppressed, which was then collected (Sudjono et al., 2012). Snail mucus was then stored at temperature of $15^{\circ} \mathrm{C}$ and avoided from the sunlight.

\section{Determination of test animal groups}

The rats that were tested had to be adapted or acclimatized for seven days before the study (Besselsen, 2004). The number of groups used in this study is based on the following formula for animal test. Twenty-four female Sprague-Dawley rats weighing $50 \mathrm{~g}$ were divided into 6 groups 
namely control group with DMBA (control DMBA induction), control group with snail mucus treatment (control group), DMBA induced with mucus dose of 15 $\mathrm{mg} / \mathrm{kg} \mathrm{BW}$ (dose I), DMBA induced with mucus dose of $20 \mathrm{mg} / \mathrm{kg} \mathrm{BW}$ (dose II), DMBA induced with mucus dose of 25 $\mathrm{mg} / \mathrm{kg} \mathrm{BW}$ (dose III), and normal rats (with no control group). Sprague-Dawley rats were randomly divided into 6 experimental groups with the code number of rats' each mammary gland as samples for the treatment test observations.

Preparation of DMBA carcinogen $(7,12-$ dimethylbenz $(\alpha)$ anthracene)

Carcinogenic DMBA was orally administered to the animal models of cancer. DMBA solution is made of a DMBA powder solution containing 7,12dimethylbenz $(\alpha)$ anthracene (DMBA) with corn oil as a solvent. The test dose calculation used a dose unit of $20 \mathrm{mg} / \mathrm{kg}$ using a sample of the highest rat BW of 200 grams, and the maximum volume of the application in rats was $1.0 \mathrm{~mL}$ (Zhao et al., 2011). The frequency of DMBA induction with injection dose in units of $20 \mathrm{mg} / \mathrm{kg} \mathrm{BW}$ with an interval of 48 hours and frequency of twice a week was ten times induction for five weeks. Carcinogenic substances were given orally (intra-gastric) by tracing the direction on the edge of the palate toward the esophagus (Sigma, 2018).

\section{Dose determination of the amount of mucus (Achatina fulica)}

Determination of the dosage of snail mucus is to reveal the inhibitory effect on cancer growth in rats induced by DMBA as cancer inducers (Sigma, 2018). Snail mucus was given in three different doses of 15, 20, and $25 \mathrm{mg} / \mathrm{kg} \mathrm{BW}$. The treatment dose was based on variations of calculating the dose of the treatment with mucus snail according to the concentration of the preliminary study and literature finding for toxicity test before treatment (Jacub et al., 2019).

Concentration in $\mathrm{mg} / \mathrm{ml}$ was obtained by defining out the preset amount of dose in $\mathrm{mg} / \mathrm{Kg} \mathrm{BW}$. While determining the dose is calculated from the maximum concentration from the highest rat weight which is 200 grams divided with the maximum volume of administration of $2.0 \mathrm{~mL}$ (Zhao et al., 2011; Meiyanto et al., 2007; Hendra, 2001). Snail mucus was given orally after DMBA induction as the post-initiation in test animals. The treatment dose was carried out at 24hour intervals immediately after macroscopic tumor examination due to DMBA induction. The dose was given twice at 24-hour intervals until the end of the trial period for the treatment dose.

\section{Mammary cancerous observation (Palpation)}

Palpation protocol in test animals was done by calculating the diameter $( \pm 50 \mathrm{~mm}$ ratio) while observing the parts of the mammary gland below the protruding part of the enlarged organ. Sometimes other parts besides the mammary duct will develop cancer in animals. Palpation aimed to determine the growth rate and diameter of cancer in rats that had been induced with DMBA as a carcinogenic part of cancerous tissue. The average cancerous lumps were obtained in centimeter unit. Mammary gland was obtained in the last observation week (Besselsen, 2004).

\section{Excision procedure-histopathological procedure}

Histopathological tissue observation was performed in Sprague-Dawley rats by removing their organs in the form of mammary glands and ovaries (Nurung et al., 2016). In mamma tissue, two parts of the tissue were made by placing them on a slide (deparaffinized) for histopathological examination using Hematoxilyn Eosin staining which caused the color of the granulation tissue of capillary endothelial cells to turn brown. The cut was excised \pm 50 $\mathrm{mm}$ off skin with a tissue as deep as fascia including 0.3 to $0.55 \mathrm{~cm}$ of mammary gland. The mamma tissue was examined by stereological histology on the cellular part (Meiyanto et al., 2007). 


\section{Statistical analysis}

Analysis was initially processed using SPSS. It was then continued using KruskalWallis nonparametric to determine the real differences of the growth and diameter of cancers among groups with a 95\% confidence level. Mann-Withney Test was the next procedure to obtain the mean among groups (Gasperz, 1991). Histopathological aspect was analyzed descriptively to find out the comparison between component layers on the cellular level and stereology.

\section{RESULTS AND DISCUSSION}

This study was purely experimental research to find out the potential components of snail mucus against carcinogenesis on laboratory animals by administering a carcinogenic chemical substance of 7,12dimethylbenz $(\alpha)$ anthracene in SpragueDawley female rats. The results were evaluated based on the growth rate and diameter of cancer in each rat, as well as histopathological analysis of the mammary organs. The treatment was carried out at the end of the $10^{\text {th }}, 12^{\text {th }}, 14^{\text {th }}$, and $16^{\text {th }}$ week. Figure 1 shows increasing cancer rates at the end of the eighth week until the end of the $16^{\text {th }}$ week ( 0 to 8 cancer lumps). This is related to the length of DMBA induction as a cause of cancer events due to mutations in somatic cells in normal rats that will become cancer cells. According to Hendra's (2001) study, induction of DMBA (7,12dimethylbenz $(\alpha)$ anthracene) and TPA was performed 12 times for 12 weeks. Cancer induction with DMBA carcinogens would be a stimulating factor for the growth of lumps over time with an average lump growth of \pm $20 \mathrm{~mm}$.

The growth results showed the diameter (cm) of the lump in cancer induction experiments with DMBA carcinogen compounds in female mice (Hennings et al., 1990). The carcinogenesis of DMBA substances is defined as the induction or increase of neoplasia in cells. Genotoxic compounds in DMBA substances (commonly formed during carcinogenesis) interact with genetic macromolecules (DNA) from carcinogen adducts. DMBA activates the kinase enzyme that influences the proliferation and differentiation of cancer cells (Pitot \& Dragan, 1996).

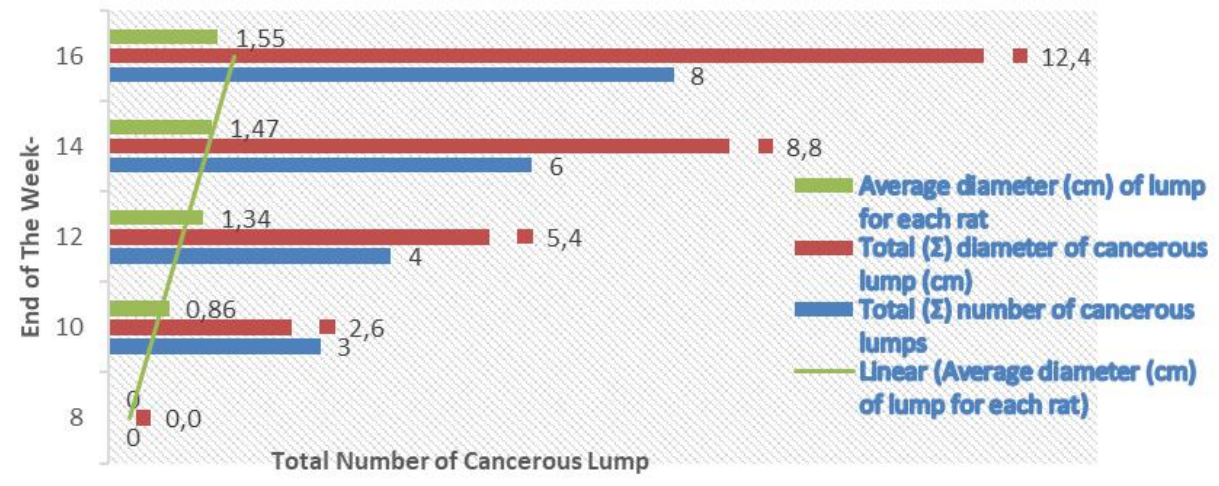

Figure 1. The number and diameter of cancerous lumps induced by DMBA in each rat.

The data of rats developing mammary cancer due to DMBA induction can be observed in the bar chart above (Figure 1). The results show that the first lump in the mammary organ channel of the rat due to the induction of DMBA cancer could already be obtained in the seventh week until the middle of the eighth week. This result is based on the study research from Wongso and Iswahyudi (2013) who reported that lumps caused by cancer first appeared in rats induced with DMBA carcinogenic substances in the eighth week until the end of the $13^{\text {th }}$ week. 
Table 1. Average growth and diameters $(\mathrm{cm})$ of rat cancerous lumps in positive control group and experimental group

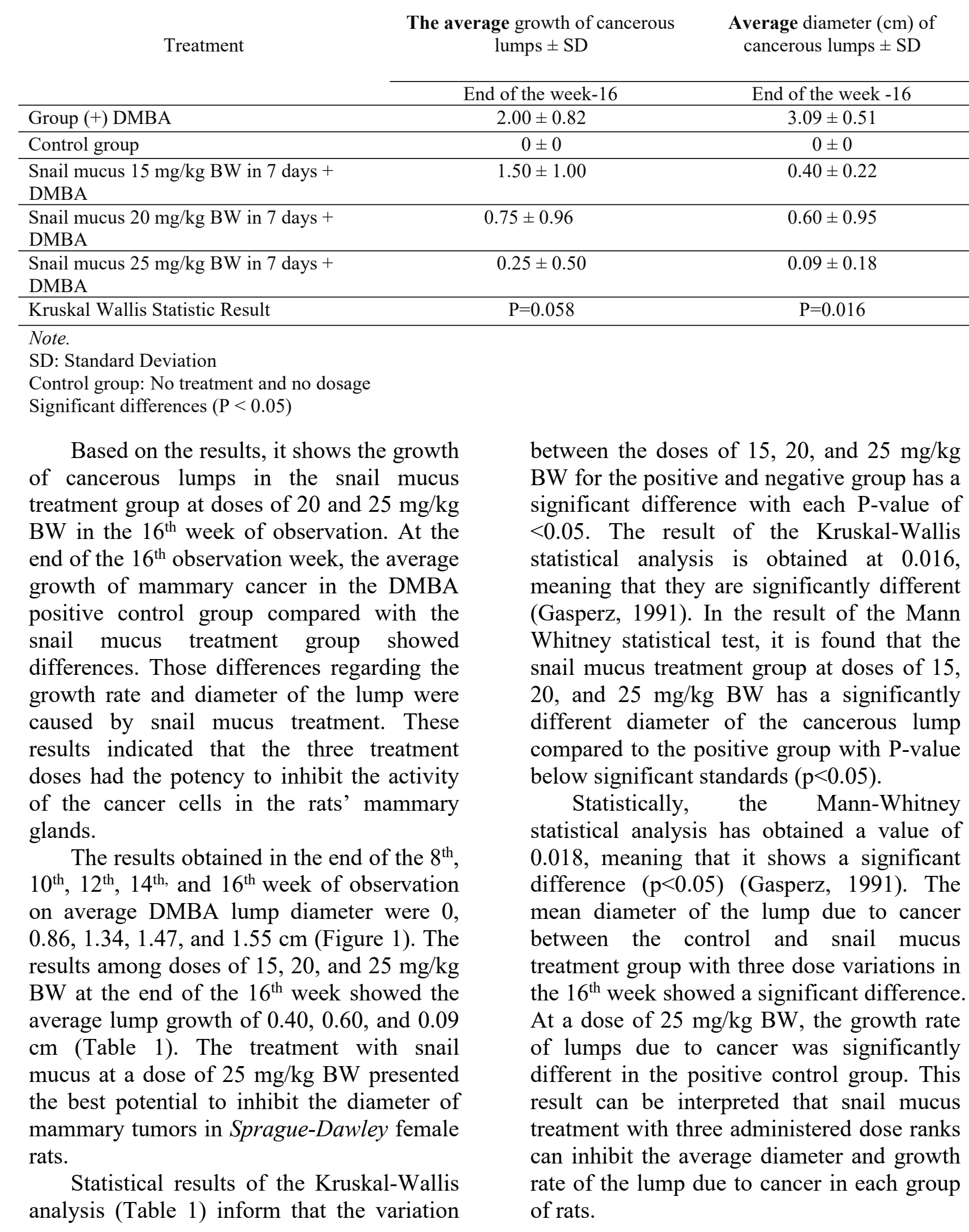



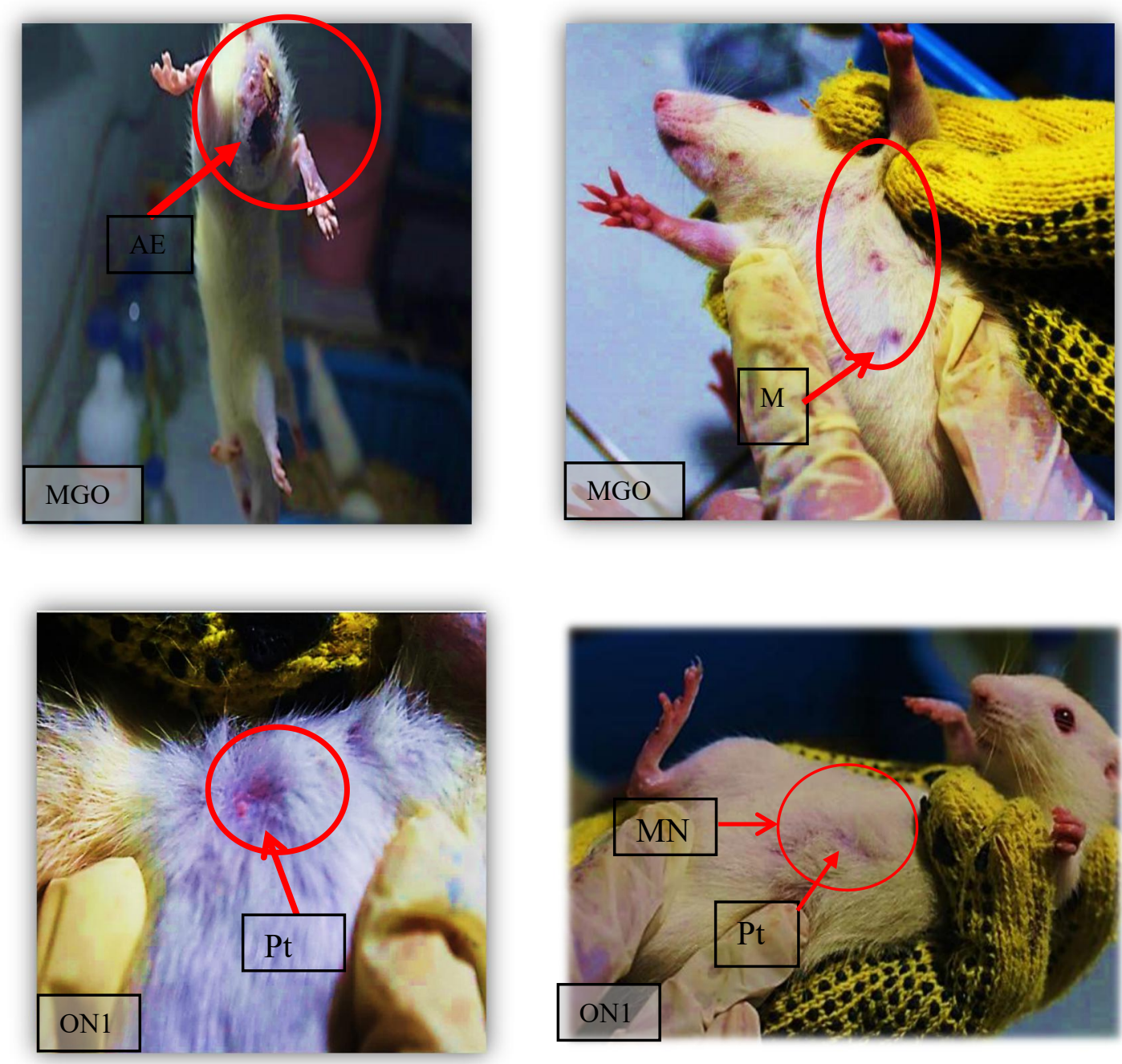

Figure 2. Macroscopic appearance in positive control group for cancer due to the induction of DMBA (palpation observing the parts of the mammary gland).

Note.

Thickening of an irregular shape resembling cancer around seeds skin (AE); there is a lump layer (Mammary Maligna) $(\mathrm{M})$; normal mammary layer $(\mathrm{MN})$; the area of the normal mammary gland organ $(\mathrm{Pt})$; mammary gland organ cancer (MGO); normal mammary gland supporting mammary tissue stratum (ON1).

The changing macroscopic palpation in the rat's body show that most cancerous growths are found in DMBA induced mammary organs (Figure 2). The mammary gland organ position is under the protruding part of the enlarged part (Hadek, 1965). The shape of the rat's mammary organ can be seen at the bottom of the rat's body. Part of the skin that protrudes out is called mammary gland (Pt). 


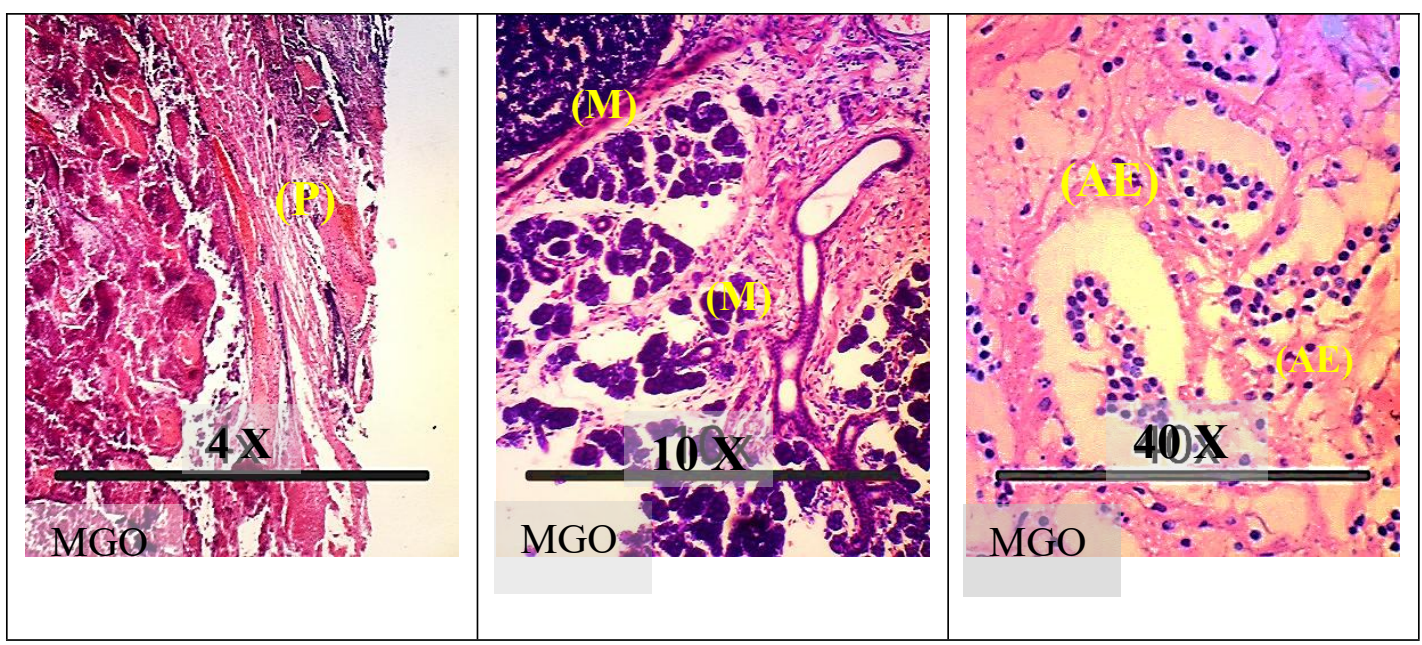

Figure 3. Histopathological picture of cancer in mammary gland due to DMBA induction (hematoxylin and eosinstaining).

Note.

Irregular epithelial thickening (AE); maligna (M); bleeding (P); mammary gland organs (MGO) at three magnifications of $4,10,40 \mathrm{X}$.

In terms of microscopic histology, some damaged structures can be found (Figure 3) namely the surface of gaps between the epithelial cells making up the faint acini layer. No duct layer is found in the histology picture because the membrane cell has been separated from the layer of the acini (Hadek, 1965). There is a coarse core chromatin accompanied with a bleeding of intestinal constituent parts of the tunica intima caused by carcinogens (Hadek, 1965; Husain et al., 2015). The initiation of a DMBA carcinogenic substance is defined as an event that occurs after administration of a chemical, physical or biological compound which can directly or indirectly change the structure of the genetic component of the cell (genotoxic).

The histopathological examination in DMBA induction group rats has revealed that the MGO mammary gland group has a thickening of the layer with irregular cell shape of the rat's mammary ducts (Figure 3). Besides the results of histopathology, there are early signs of growth and development towards cancer (malignant) in the form of hyperplasia. The histopathological picture depicts that DMBA initiates cancer in the duct and mammary glands of rats (Figure 3) (Nansi et al., 2015; Constantinou et al., 2003; Hadek, 1965).

Histopathological picture of the mammary group of rats (ON1), appearing on normal mammary gland (Figure 4) is a component of the lactic duct (D) coated with epithelium arranged by connective tissue $(4 \mathrm{x}$ magnification) (Nansi et al., 2015). The presence of an acini (As) component in a thin layer of tissue stratum without cancerous growth shows a normal histological picture. One to two layers of column epithelial cells appear around the part of the lactating duct (Husain et al., 2015).

The results of the analysis of other histopathological groups show that there is no cancer in groups treated with snail mucus for each dose. The results of histopathology, when compared with the histopathology of normal mammary organ channels, show similarity in cell shape marked by the presence of the components making up the cell layer (Figure 4) (Meiyanto et al., 2007). The third dose of snail mucus of $25 \mathrm{mg} / \mathrm{kg} \mathrm{BW}$ treatment does not show the occurrence of cancer lump in descript results on rat's mammary. 


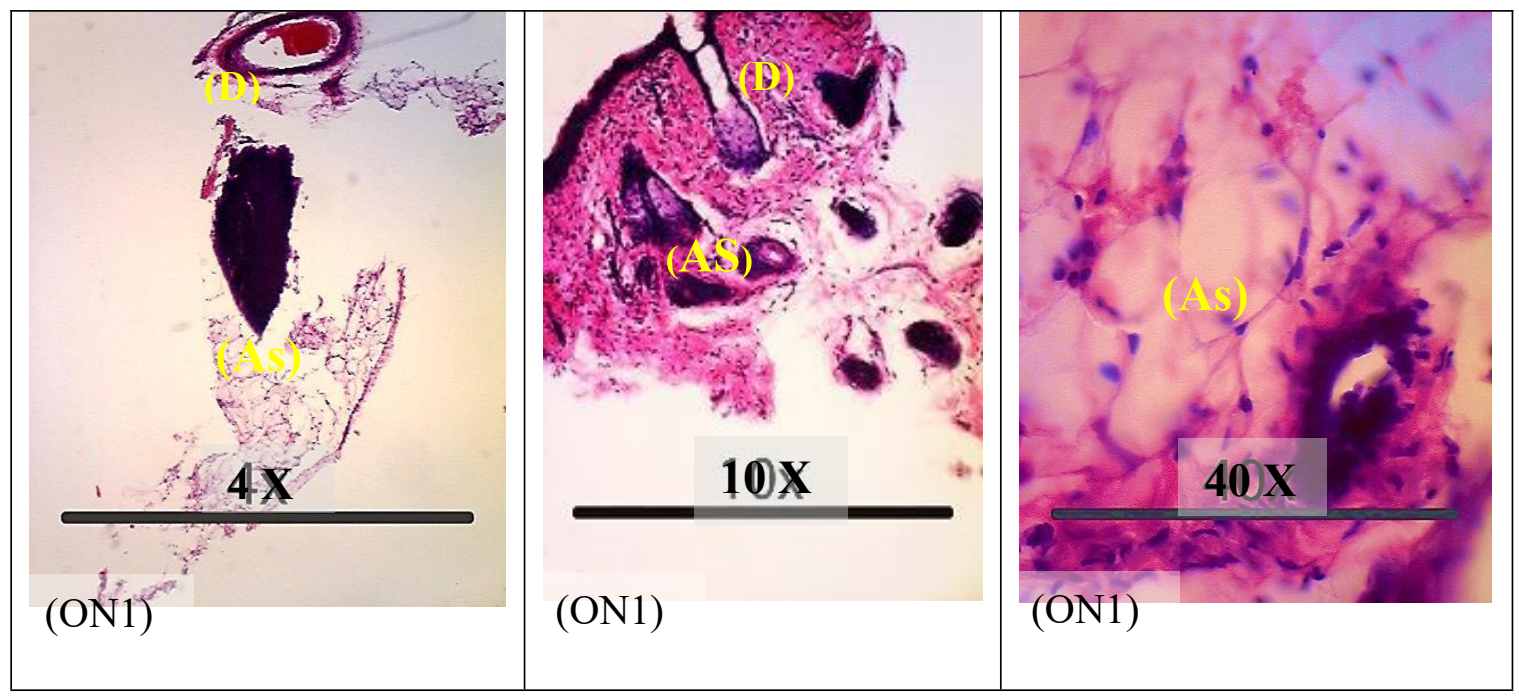

Figure 4. Histopathological features in normal group rats (hematoxylin and eosin staining).

Note.

The main component in the mammary organ Asinus (As); Duct (D); (ON1) normal group mammary gland organs three magnifications $4,10,40 \mathrm{X}$.

Histopathological group analysis results show a description of mammary organ channels in the ovaries and mammary glands (three-dose) in a descriptive comparison to groups with abnormal tissue stratum (Meiyanto et al., 2007; Hadek, 1965). From the results of the histopathological test, it is revealed that snail mucus has the potential inhibitory activity on cancer giving cytotoxic effects on an animal cell. Empirically concluding, snail mucus is potential for use as cancer inhibition in female Sprague-Dawley rats.

Snail mucus at a dosage of $25 \mathrm{mg} / \mathrm{kg} \mathrm{BW}$ may contain flavonoids in the mucus bioactive components (Constantinou et al., 2003; Jacub et al., 2019) or other flavonoids such as phenoxodiol, genistein, and tamoxifen. According to research findings by Constantinou et al. (2003), component flavonoids can inhibit protein synthesis by deactivating topoisomerase from eukaryotic initiation which then causes phosphorylation in topoisomerase II, so that it fails to initiate mRNA translation in the tumor cell cycle. Some flavone derivatives can suppress tumor cell growth by inhibiting various types of metabolic enzymes one of which is Topoisomerase II which is needed for DNA replication and allows the separation of chromosomes. The ability to inhibit protein synthesis has been found in rat and human cells (Hendra,2011; Constantinou et al., 2003).

Snail mucus is a secretory natural material from snails with a yellowish color containing $4 \mathrm{mg} / \mathrm{cm}^{3}$ of protein and various amino acids (Ekobon et al., 2016). Extract science data from some literature, state that Snail mucus contains phenoxodiol flavonoid derivatives, glycoprotein, mytimacin-AF, glycosaminoglycan, and achasin which are effective in inhibiting breast cancer cells (Constantinou et al., 2003; Ekobon et al., 2016). Recent research from Poland shows that tissue extracted from Helix aspersa snails has a chemo preventive healing effect on colon cancer cells (Matusiewicz et al., 2018).

\section{CONCLUSION}

It can be concluded that snail mucus has an inhibitory effect on the growth and diameter of mammary cancer in female Sprague-Dawley rats induced by 7,12dimethylbenz $(\alpha)$ anthracene (DMBA). Snail mucus at a dose of $25 \mathrm{mg} / \mathrm{kg}$ BW for 7 consecutive days can potentially inhibit the growth and diameter of cancer in rats induced by DMBA. Histopathological picture of the mammary organ channel shows that there are different histological features between groups receiving snail mucus treatment with three variations of doses and the positive control group induced with 7,12- 
dimethylbenz $(\alpha)$ anthracene (DMBA) cancer in rats' mammary.

Suggestion for further research includes the need for fractionation, isolation, and purification of specific bioactive compounds of snail mucus treatment samples. Research can be continued using different and more specific objects like human cell cultures through preliminary cytotoxic applications in the cancer cell.

\section{REFERENCES}

Besselsen, D.G., 2004. Biology of Laboratory Rodent. Medical Books, 11-35.

Constantinou, A. I., Mehta, R., and Husband, A., 2003. Phenoxodiol, A Novel Isoflavone Derivative, Inhibits 7,12dimethylbenz $[\alpha]$ anthracene (DMBA)Induced Mammary Carcinogenesis in Female Sprague-Dawley Rats. European Journal of Cancer, 39, 1012-1018.

Ekobon, T., Pennapa, T., Sittiruk, R., Ladda, M., and Pramote, C., 2016. Prediction of anticancer peptides against MCF-7 breast cancer cells from the peptidomes of Achatina fulica mucus fraction. Computational and Structural Biotechnology Journal, 14, 49-57.

Gasperz, V., 1991. Metode Perancangan Percobaan. Armico, 7-11.

Globocon, 2018. Global Cancer Observatory IARC. WHO, Geneva. [WWW Document] URL http://gco.iarc.fr/ (accessed 30.08/18).

Hadek, R., 1965. The Structure of the Mammalian Egg in: Bourne, G.H., and Danielli, J.F. Review of Cytology, 18, 29-68.

Hendra, P., 2001. Pengaruh Praperlakuan Perasan Rimpang Temu Putih Curcuma zedoria (Berg.) Rosc. Terhadap Pertumbuhan Papiloma Kulit Mencit Akibat Pemberian Dimetilbenzantrasen dan Tetradekanoil Forbol Asetat. Disertation. Department of Pharmacy, Gadjah Mada University, Yogyakarta.

Hendra, R., Ahmad, S., Oskoueian, E., Sukari, A., and Shukor, M.Y., 2011.
Antioxidant, Anti-inflammatory and Cytotoxicity of Phaleria macrocarpa (Boerl.) Scheff Fruit. BMC Complementary and Alternative Medicine, 11, 110.

Hennings, H., Shores, R.A., Poirier, M.C., Reed, E., Tarone, R.E., and Yuspa, S.H., 1990. Enhanced Malignant Conversion of Benign Mouse Skin Cancers by Cisplatin., J. Natl Cancer Instrument, 82, 836-840.

Husain, N.P., Kairupan,C.F., and Durry, M.F., 2015. Gambaran Histopalogik Payudara Mencit (Mus muscullus) yang Diinduksi dengan Senyawa Karsinogenik benzo( $\alpha)$ pyrene dan Diberikan Ekstrak Buah Mengkudu (Morindacitrifolia L.). Jurnal eBiomedik, 3(1), 521-523.

Hoffman, T., Nicole, P., Felicitas, A., Dan, C. and Angela, M., 2014. Achatina fulica Giant African Snail. [WWW Document] URL https//animaldiversity.org/accounts/ Achatinafulica/\#26E00FDC-B21611E3-BDEE-002500F14F28 (accessed 23.07.19).

Islam, T., and Linhart, R.J., 2003. Chemistry, Biochemistry and Pharmaceutical Potentials of Glikosaminoglikan and Related Saccharides in Chi-huey Wong (editor), Carbohydrate-based Drug Discovery, 1, 407-433.

Jacub, C., Sidharta, B.R., Zahida,F and Edison, A., 2019. Toksisitas senyawa bioaktif dari lendir bekicot (Achatina Fulica) dengan metode Brine Shrimp Lethality Test. Proceeding Seminar, pp. 33-50.

Matusiewicz, M., Kosieradzka, I., Niemiec, T., Grodzik, M., Antushevich, H., Strojny, B., and Gołebiewska, M., 2018. In Vitro Influence of Extracts from Snail Helix aspersa (Müller) on the Colon Cancer Cell Line Caco-2. Int. J. Mol. Sci, 19(1064), 1-23.

Meiyanto, E., Susilowati, S., Tasminatun, S., Murwanti, R., and Sugiyanto., 2007. Chemopreventive Effect of Ethanolic Extract of Gynura procumbens (Lour), 
Merr on the Carcinogenesis of Rat Breast Cancer Development. Majalah Farmasi Indonesia, 18(3), 154-162.

Nansi, E.M., Durry, M.F., and Kairupan, C., 2015. Gambaran Histopatologik Payudara Mencit (Mus musculus) yang Diinduksi benzo $(\alpha)$ pyrene Diberikan Ekstrak Kunyit (Curcuma longa L.). Jurnal e-Biomedik, 3(1), 511-513.

Nurung, A, H., Herwiyanti, S., and Paramita, D.K., 2016. Effect of 1.2-epoxy-3[33[3.4-dimetoxyi- phenil]-4h-1benzopiran-4-on] Propane (epi) on Sirtuin-1 and Nuclear Factor-kB Expression of DMBA induced Mammary Tumors in Sprague Dawley Rats. Journal Medical Sciences, 48(3), 142-153.

Patrick, G. L., 2013. Anticancer Agents: An Introduction to Medicinal Chemistry, 523-525.

Pitot, H.C., and Dragan, Y.P., 2001. Chemical Carcinogenesis in Casarett and Doull's Toxicology: The Basic Science of Poison, Six Edition, 164165.

Sigma Aldrich, 2018. Product Identification $\mathrm{C}_{20} \mathrm{H}_{16} \quad$ DMBA $\quad(7,12$ Dimethylbenz(a)anthracene D3524. Page 1-8. Sigma-Aldrich Co. LLC. Chemical License Product, Singapore.
Sudjono, T. A., Mimin, H., and Yunita, R. P., 2012. Pengaruh Konsentrasi Gelling Agent Carbomer 934 dan HPMC pada Formulasi Gel Lendir Bekicot (Achatina fulica) terhadap Kecepatan Penyembuhan Luka Bakar pada Punggung Kelinci. Pharmacon, 13(1), 6-11.

Vermeulen, J. J., and Whitten, A. J., 1998. Fauna Malesiana Field and Study Guide to the Land Snails Series, 90-91; 148.

Wongso, H., and Iswahyudi, 2013. Induksi kanker pada tikus putih SpragueDawley sebagai hewan model dalam penelitian radiofarmaka. Prosiding Seminar Nasional Sains dan Teknologi Nuklir, BATAN, Bandung.

Zhao, J. A., Chen, J. J., Ju, Y. C., Wu, J. H., Geng, C. Z., and Yang, H. C., 2011. The Effect of Childbirth on Carcinogenesis of DMBA-Induced Breast Cancer in Female SD Rats. Chinese Journal of Cancer, 30(11), 779-783. 